\title{
STUDIES ON SOME MILK BORNE PATHOGENS
}

\author{
SAADIA H.H. EL-SHINAWY ${ }^{1}$; GAMAL M. HASSAN ${ }^{1}$; MOHAMED A.H. El-SHATER ${ }^{2}$ and \\ SHIMAA A. ABD El-AZIZ ${ }^{2}$ \\ ${ }^{1}$ Food Hygiene Department, Faculty of Veterinary Medicine, Beni-Suef University \\ ${ }^{2}$ Animal Health Research Institute, Egypt
}

Received: 26 August 2018; Accepted: 20 September 2018

\begin{abstract}
The objective of this study was to assess the degree of contamination of raw and pasteurized milk with bacteria of the genus Staphylococcus aureus, Listeria monocytogenes and Escherichia coli O157: H7. A total of 200 milk samples (150 raw and 50 pasteurized) were purchased from different sources; farms, collecting centers, dairy shops and different super markets in El-Minia governorate, Egypt. The samples were examined bacteriologically and presumptive isolates were further confirmed by PCR using specific primers of Staph. aureus clfA gene, L. monocytogenes $16 \mathrm{~S}$ rRNA gene and serotyping of $E$. coli isolates. The overall incidence of Staph. aureus was $64 \%$ and $4 \%$ in raw and pasteurized milk, respectively, while L. monocytogenes was present in $8 \%$ of raw milk and couldn't be detected in pasteurized milk. Moreover, E. coli O157: H7 could not be detected in any samples. In conclusion, raw milk represents a public health hazard for human consumption in relation to milk borne pathogens.
\end{abstract}

Key words: Raw milk, Pasteurized milk, Staphylococcus aureus, Listeria monocytogenes, Escherichia coli O157:H7, Public health.

\section{INTRODUCTION}

Since ancient times, milk form a major part of human food and play a prominent role in the diet (Pal, 2014). Raw milk is known as the main transmission pathway for pathogens resulting in food borne outbreaks every year (Gillespie et al., 2003; Rey et al., 2003). Pasteurization process of milk is a heat treatment intended to reduce the number of any harmful microorganisms to a level at which they do not constitute a significant health hazard (MPI NZ, 2013).

Staphylococcus. aureus is one of the major bacterial agents causing food borne diseases in human worldwide (EFSA, 2010). It is an opportunistic pathogen, which associated with food poisoning and food spoilage (Argudin et al., 2010). The staphylococcus food poisoning is a mild intoxication occurring after ingestion of food containing from 20ng up to $1 \mathrm{ug}$ of Staphylococcal enterotoxins (SEs) which is enough to induce symptoms in human beings (Nermano et al., 2007). Clinical signs of Staphylococcal food poisoning generally disappear within 24-48 h. Deaths occur rarely and specifically in the young or elderly (Jay et al., 2005).

Corresponding author: Dr. SHIMAA A. ABD El-AZIZ E-mail address: shimaa_ahmed1415@yahoo.com Present address: Animal Health Research Institute, Egypt
Listeria monocytogenes is considered as one of the most important food borne pathogen that induce serious and potentially life threatening illness known as listeriosis in humans and animals (Rahimi et al., 2012) with high mortality rate (20-30\%) (Wijendra et al., 2014). It may range from non -invasive febrile gastroenteritis or influenza like symptoms especially in healthy individuals with no predisposing conditions (Aygun and Pehlivanlar, 2006) to serious invasive severe symptoms which may lead to septicemia, meningitis and abortion (Shamloo et al., 2015; Kevenk and Gulel, 2016).

Enterohemorrhagic Escherichia coli (EHEC) have emerged as an important cause of human intestinal diseases in developed countries over the past 20 years (Naylor et al., 2003). E.coli O157:H7 causes both outbreaks of diarrhea, haemorrhagic colitis and haemorragic uremic syndrome (HUS) (Baker et al., 2007). The infectious dose was very low about 100200 organisms or even less than 10 cells in susceptible consumers which is hazardous and increased the risk of disease (CFSPH, 2009; Grant et al., 2011). In addition, its ability to produce Shiga toxins (Stxs) (formerly called Shiga-like toxins) (Beneduce et al., 2003) which is considered as best essential virulence factor for $E$. coli O157:H7 in human disease (Mauro and Koudelka, 2011).

Therefore, the present study aimed to study the incidence of some foodborne pathogens, as Staph. 
aureus, L. monocytogenes and E.coli O157:H7 in raw and pasteurized milk in El-Minia governorate with regarding to public health.

\section{MATERIALS AND METHODS}

\section{Collection of Samples:}

a-Raw milk: One hundred and fifty raw milk samples were purchased from 3 different sources as farms, dairy shops and collecting centers (50 each) in ElMinia governorate. All samples were collected in clean, dry, sterile containers and delivered as soon as possible to the laboratory in an insulated ice box, proved to be raw by storch's test according to the method recommended by FDA (1998) and examined at the same day.

b- Pasteurized milk: Fifty samples of pasteurized milk (bottles or cartons) were collected from different supermarkets and shops of different manufacture dates and different companies in El-Minia governorate. All bottles and cartons were thoroughly cleaned from outside and then well mixed and aseptically opened.

2- Enumeration, Isolation and identification of Staph. aureus:

By the using of Baird Parker's agar plates supplemented with egg yolk and potassium tellurite, the method recommended by APHA (2004) was applied.

\section{3- Isolation and identification of $L$. monocytogenes:} By the using of PALCAM agar, the plates were incubated at $35^{\circ} \mathrm{C}$ for 48 hours according to Hitchins (2001).

\section{Oligonucleotide primers sequences.}

\begin{tabular}{|c|c|c|c|c|}
\hline Microbial agent & Target gene & $\begin{array}{c}\text { Oligonucleotide Sequence } \\
\left(5^{\backslash}-3^{\backslash}\right)\end{array}$ & $\begin{array}{c}\text { Amplified product } \\
\text { size }(\mathrm{pb})\end{array}$ & Reference \\
\hline L. monocytogenes & $\begin{array}{c}16 S \\
r R N A\end{array}$ & $\begin{array}{c}\text { GGACCGGGGCTAATA } \\
\text { CCGAATGAT AA } \\
\text { TTCATGTAGGCGAGTT } \\
\text { GCAGCCT A }\end{array}$ & $1200 \mathrm{bp}$ & $\begin{array}{l}\text { Kumar et al. } \\
\quad \text { (2015) }\end{array}$ \\
\hline Staph. aureus & ClfA & $\begin{array}{c}\text { GCAAAATCCAGCACAA } \\
\text { CAGGAAACGA } \\
\text { CTTGATCTCCAGCCAT } \\
\text { AATTGGTGG } \\
\end{array}$ & $638 \mathrm{bp}$ & $\begin{array}{l}\text { Mason et al. } \\
\quad(2001)\end{array}$ \\
\hline
\end{tabular}

Cycling conditions of the different primers during CPCR

\begin{tabular}{cccccccc}
\hline Microbial agent & Gene & $\begin{array}{c}\text { Primary } \\
\text { denaturation }\end{array}$ & $\begin{array}{c}\text { Secondary } \\
\text { denaturation }\end{array}$ & Annealing & Extension & $\begin{array}{c}\text { No.of } \\
\text { cycles }\end{array}$ & $\begin{array}{c}\text { Final } \\
\text { extension }\end{array}$ \\
\hline L.monocytegenes & $16 \mathrm{~S}$ & $94^{\circ} \mathrm{C}$ & $94^{\circ} \mathrm{C}$ & $60^{\circ} \mathrm{C}$ & $72^{\circ} \mathrm{C}$ & 35 & $72^{\circ} \mathrm{C}$ \\
& rRNA & $5 \mathrm{~min}$. & $30 \mathrm{sec}$ & $1 \mathrm{~min}$. & $1 \mathrm{~min}$. & $12 \mathrm{~min}$. \\
\hline Staph. aureus & clfA & $94^{\circ} \mathrm{C}$ & $94^{\circ} \mathrm{C}$ & $55^{\circ} \mathrm{C}$ & $72^{\circ} \mathrm{C}$ & 35 & $72^{\circ} \mathrm{C}$ \\
& & $5 \mathrm{~min}$. & $30 \mathrm{sec}$. & $45 \mathrm{sec}$. & $45 \mathrm{sec}$. & $10 \mathrm{~min}$. \\
\hline
\end{tabular}


6.3. Detection and identification of PCR product.

The amplified DNA fragments were resolved by agarose gel electrophoresis, stained with ethidium bromide $(0.5$ $\mu \mathrm{g} / \mathrm{ml}$ ) and the gels can be screened and pictured under UV light.

\section{RESULTS}

Table 1: Incidence of Staph .aureus in the examined raw milk samples.

\begin{tabular}{cccc}
\hline \multirow{2}{*}{ The samples origin } & No. of the examined samples & \multicolumn{2}{c}{ Positive samples } \\
\cline { 3 - 4 } & & No. & $\%$ \\
\hline Farms & 50 & 45 & $90 \%$ \\
\hline Collecting Centers & 50 & 24 & $48 \%$ \\
\hline Dairy shops & 50 & 27 & $54 \%$ \\
\hline Total & 150 & 96 & $64 \%$ \\
\hline
\end{tabular}

Table 2 : Statistical analytical results of Staph. aureus count/ml in the examined milk samples.

\begin{tabular}{ccccc}
\hline The samples origin & $\begin{array}{c}\text { No. of } \\
\text { examined } \\
\text { samples }\end{array}$ & Minimum & Maximum & Mean \pm SEM \\
\hline Farms & 50 & $2.2 \times 10^{2}$ & $2.68 \times 10^{4}$ & $5.45 \times 10^{3} \pm 1.15 \times 10^{3}$ \\
\hline Collecting centers & 50 & $2 \times 10$ & $1.06 \times 10^{4}$ & $1.80 \times 10^{3} \pm 3.96 \times 10^{2}$ \\
\hline Dairy shops & 50 & $8 \times 10$ & $1.5 \times 10^{6}$ & $9.78 \times 10^{4} \pm 5.06 \times 10^{4}$ \\
\hline Pasteurized milk & 50 & 30 & 60 & $1.8 \pm 1.3$ \\
\hline
\end{tabular}

Table3: Frequency distribution of the positive samples based on their Staph. aureus count/ml.

\begin{tabular}{|c|c|c|c|c|c|c|c|c|}
\hline \multirow{3}{*}{$\begin{array}{l}\text { Intervals } \\
\text { cfu/ml }\end{array}$} & \multicolumn{6}{|c|}{ Raw milk } & \multicolumn{2}{|c|}{ Pasteurized milk } \\
\hline & \multicolumn{2}{|l|}{ Farm } & \multicolumn{2}{|c|}{ Collecting centers } & \multicolumn{2}{|c|}{ Dairy Shops } & \multirow[b]{2}{*}{ No. } & \multirow[b]{2}{*}{$\%$} \\
\hline & No. & $\%$ & No. & $\%$ & No. & $\%$ & & \\
\hline $10-<10^{2}$ & 0 & 0 & 4 & 16.7 & 2 & 7.4 & 2 & 100 \\
\hline $10^{2}-<10^{3}$ & 31 & 68.9 & 9 & 37.5 & 5 & 18.5 & 0 & 0 \\
\hline $10^{3}-<10^{4}$ & 4 & 8.9 & 9 & 37.5 & 10 & 37.1 & 0 & 0 \\
\hline $10^{4}-<10^{5}$ & 10 & 22.2 & 2 & 8.3 & 8 & 29.6 & 0 & 0 \\
\hline$>10^{5}$ & 0 & 0 & 0 & 0 & 2 & 7.4 & 0 & 0 \\
\hline Total & 45 & $100 \%$ & 24 & $100 \%$ & 27 & $100 \%$ & 2 & $100 \%$ \\
\hline
\end{tabular}

Table 4: Acceptable and unacceptable samples of the examined milk samples based on their Staph. aureus count $/ \mathrm{ml}$. according to the Egyptain standards (2005).

\begin{tabular}{|c|c|c|c|c|c|}
\hline \multirow{2}{*}{ Source of the samples } & \multirow{2}{*}{ Permissible limit } & \multicolumn{2}{|c|}{ Acceptable samples } & \multicolumn{2}{|c|}{ Unacceptable samples } \\
\hline & & No. & $\%$ & No. & $\%$ \\
\hline Farm & $\begin{array}{l}\text { Must be not more than } \\
\qquad 10^{2}\end{array}$ & 5 & 10 & 45 & 90 \\
\hline Collecting centers & $\begin{array}{l}\text { Must be not more than } \\
\qquad 10^{2}\end{array}$ & 30 & 60 & 20 & 40 \\
\hline Dairy shops & $\begin{array}{l}\text { Must be not more than } \\
\qquad 10^{2}\end{array}$ & 25 & 50 & 25 & 50 \\
\hline Pasteurized milk & Must be 0 & 48 & 96 & 2 & 4 \\
\hline
\end{tabular}


Table 5: Incidence of L. monocytogenes in the examined raw milk samples.

\begin{tabular}{cccc}
\hline \multirow{2}{*}{ The samples origin } & No. of examined samples & \multicolumn{2}{c}{ Positive samples } \\
\cline { 3 - 4 } & & No. & $14 \%$ \\
\hline Farms & 50 & 7 & $4 \%$ \\
\hline Collecting Centers & 50 & 2 & $6 \%$ \\
\hline Dairy shops & 50 & 3 & $8 \%$ \\
\hline Total & 150 & 12 & $8 \%$ \\
\hline
\end{tabular}

Table 6: Some E.coli serotypes isolated from the examined raw milk samples.

\begin{tabular}{ccc}
\hline The samples origin & Poly Valent & Mono Valent \\
\hline \multirow{2}{*}{ Farms } & 3 & O114 \\
\cline { 2 - 3 } & 3 & O142 \\
\hline \multirow{2}{*}{ Dairy shops } & 1 & O86a \\
\cline { 2 - 3 } & 2 & O146 \\
\hline
\end{tabular}

Table 7: Incidence of Staph .aureus, L. monocytogenes and E. coli O157:H7 in the examined pasteurized milk samples.

\begin{tabular}{ccccccc}
\hline $\begin{array}{c}\text { No. of the examined } \\
\text { samples }\end{array}$ & Staph.aureus & L. monocytogenes & \multicolumn{2}{c}{$\begin{array}{c}\text { E. coli } \\
\text { O157:H7 }\end{array}$} \\
\hline 50 & No. & $\%$ & No. & $\%$ & No. & $\%$ \\
\cline { 2 - 7 } & 2 & 4 & 0 & 0 & 0 & 0 \\
\hline
\end{tabular}

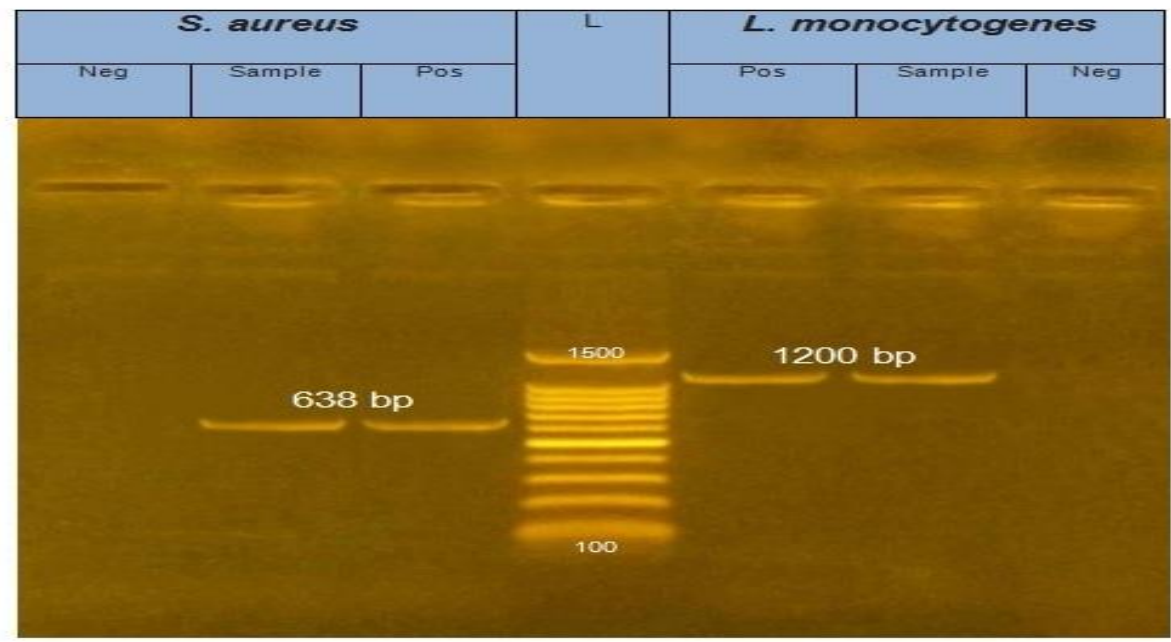

Photo1: PCR results for Staph. aureus clfA gene and L. monocytogenes 16S rRNA gene showing positive amplification 638 bp of Staph. aureus clfA gene and 1200 bp of L. monocytogenes 16S rRNA gene, L showed [Gelpilot100 bp plus ladder (Qiagen, 100-1500 bp)].

\section{DISCUSSION}

The results illustrated in Table 1 revealed that, 96 $(64 \%)$ of the examined raw milk samples were contaminated with Staph. aureus. Nearly similar findings $52 \%$ and $56.66 \%$ was reported by Pourhassan and Taravat (2011); El-Jakee et al. (2013), respectively. However, higher results of Staph.aureus isolated from cow's milk reported by
Al-Tarazi et al. (2003); Ekici et al. (2004) in percentages of 80 and $75 \%$ respectively. While, lower results were estimated by Jahan et al. (2015); Ayele et al. (2017) in percentages 25.3 and $23.4 \%$ respectively.

Staph. aureus are wide spread in nature, up to $50 \%$ of humans may carry this organism in their nasal passages, throats and on their hair and skin. So it is 
good indicator of the personal hygiene of the workers with respiratory infections (Kamat et al., 1991; Harvey and Gilmour, 1996).

The results in Table 4 proved that $10 \%, 60 \%, 50 \%$ and $96 \%$ of the milk samples from farms, collecting centers, dairy shops and pasteurized milk respectively were acceptable for the Staph. aureus $\mathrm{cfu} / \mathrm{ml}$ according to the Egyptian standards (2005).

The obtained results reported in Table 5 reveals that raw milk was contaminated with $L$. monocytogenes with an overall incidence of $8 \%$. Nearly similar results were recorded by El-Malt and AbdelHameed (2009); El-Marnissi et al. (2013); Kevenk and Gulel (2016). Meanwhile, these results disagreed with those recorded by Sammarco et al (2005); Aygun and Pehlivanlar (2006); Atil et al. (2011) who failed to isolate L. monocytogenes.

The sources of Listeria spp. in raw milk have been reported to be faecal (Griffiths, 1989) and environmental contamination during milking, storage and transport, infected cows in dairy farms and poor silage quality (Bemrah et al., 1998). High contamination of milk with $\mathrm{L}$. monocytogenes in autumn and winter when silages are fed. Broseta $e t$ al. (2003) also reported that contamination of raw milk with L. monocytogenes is usually more common in the winter, most likely because silage feeding in many parts of the world is more common in that season. In addition, a large number of studies have indicated that clinical listeriosis in ruminants is often associated with feeding poor quality silage (Boerlin et al., 2002).

Silage is not widely used as animal feed in ElMinia governorate, Egypt.; the animals were fed with dry feed and some green grass. Therefore, the contamination source of $L$. monocytogenes in raw milk in this study may be of fecal and environmental contamination during milking, storage and transport, infected animals in dairy farms. Furthermore, most cattle and sheep farms in Egypt do not have adequate hygiene precautions and animals live in a natural environment together with people.

E.coli O157: $H 7$ could not be detected in all of the examined samples using conventional culture, biochemical and serological methods. Serological identification of the isolated $E$. coli are listed in Table 6 where serotypes O114, O142, O86a and O 148 were detected.

The obtained results was in line with the results obtained by Coia et al. (2001); Dontorou et al. (2003); Meshref (2007); Issa et al. (2010); Zeinhom (2011) who couldn't isolate E. coli O157 H7 from raw milk examined in Netherlands, Greece, Turkey and Egypt respectively. On the contrary the current results disagreed with others like Abdel Khalek et al. (2001); Amer and Soliman (2004); El-Gedawy et al. (2016) who reported 3, 1 and $1 \%$ of raw milk examined in Egypt were contaminated with E. coli O157:H7

The failure in detection of E. coli $0157: H 7$ in milk is mainly returned to its presence sporadically at very low levels among very high levels of competitor organisms (Siriken et al., 2006). It can be thought that there is very low risk, but on the other hand, this bacterium can survive for more than 50 days in municipal reservoir and lake water (Wang and Doyle, 1998) and dairy cattle are asymptomatic carriers of this bacterium (Zhao et al., 1995; Wang et al., 1997; Heuvelink et al., 1998), thus increasing the risk for transmission through cattle to cattle, milk and milk products and to other foods.

As recorded in Table 7 it was apparent that out of the 50 examined samples of pasteurized milk, Staph. aureus was isolated from 2 samples (4\%). This result was similar to that obtained by Vahedi et al. (2013). While higher percentages were recorded by Gündog an et al. (2006); Rall et al. (2008); De Oliveira et al. (2011). Unlike, Leite et al. (2002); Ayele et al. (2017) did not detect Staph. aureus in the pasteurized milk in Salvador and Ethiopia respectively.

The presence of Staph. aureus in pasteurized samples can be explained either by postpasteurization contamination or by the presence of heat resistant strain. When heat treatment process is ineffective; faulty pasteurization will not destroy all foodborne pathogens (Kadariya et al., 2014). Insufficiently cleaned milk equipment was the most frequently incriminated source of pasteurized milk contamination with Staph. aureus.

It was clear from the data showed in Table 7 that $\mathrm{L}$. monocytogenes could not be detected in all of the examined samples. These results are in agreement with those obtained by Baek et al. (2000); Padilha et al. (2001); Abd El Aal and Atta (2009). On the contrary, the current results disagreed with others like, Ahmed and Hussein (2005); Seyoum et al. (2015) as they reported 4 and $1 \%$ of pasteurized milk examined were contaminated with $\mathrm{L}$. monocytogenes.

Similarly E. coli $0157: H 7$ couldn't be detected in pasteurized milk, unlike Upton and Coia (1994) who could isolated it after occurring an outbreak of E. coli 0157 infection associated with pasteurized milk supply. This outbreak resulted in 9 children developing haemolytic uraemic syndrome (HUS) and one elderly woman developing thrombotic thrombocytopenia purpura (TTP). 
It was concluded that, some milk borne pathogens like Staph. aureus and L. monocytogenes could be isolated from raw milk, in which it is unsafe for human consumption.

\section{REFERENCES}

Abd El Aal, S.F.A and Atta, M.A-H.B. (2009): Occurance of listeria and yersinia species in milk and milk products. Assuit Vet, Med. J,123(55): 89-99.

Abdel-Khalek, A.; El Gaml, A. and El-Sherbini, M. (2001): Prevalence of Esherichia coli O157:H7 in milk and faeces of dairy farm animal in Dakahlia province. $1^{\text {st }}$ Congress of food hygiene and human health, 6-8 February 2001. Dep. Of Food Hygiene, Fac.Vet. Med., Assiut Univ., Egypt.271-279.

Ahmed, E.K. and Hussein, S.Z. (2005): Incidence of listeria monocytogenes in pasteurized milk and some pasteurized milk products and effect of boiling on its viability. Assuit Vet, Med. J.105(51): 89-99.

Al-Tarazi, Y.; Al-Zamil, A.; Shaltout, F. and AbdelSamei, H. (2003): Sanitary status of raw cow milk marketed in northern Jordan. Assuit Vet, Med. J. 49(96): 180-194.

Amer, A.A. and Soliman, N.F. (2004): Prevalence of enterohaemorrhagic Escherichia coli O157: $H 7$ in raw milk and effect of some chemical preservatives on its viability. Assuit Vet, Med. J. 50 (102), 33-47.

APHA "American Public Health Association" (2004): Compendium of Methods for the Microbiological Examination of Food. 17 $7^{\text {th }}$ Ed., Washingaton D.C.USA.

Argudin, M.A.; Mendoza, M.C.; and Rodicio, M.R. (2010): Food Poisoning and Staphylococcus aureus Enterotoxins, Toxins 2 (7): 17511773.

Atil, E.; Ertas, H.B. and Ozbey, G. (2011): Isolation and molecular characterization of Listeria spp. from animals, food and environmental samples. J. Veterinarni Medicina, 56 (8): 386-394

Ayele, Y.; Gutema, F.D.; Edao, B.M.; Girma, R.; Tufa, T.B.; Beyene, T.J.; Tadesse, F.; Geloye, M. and Beyi, A.F. (2017): Assessment of Staphylococcus aureus along milk value chain and its public health importance in Sebeta, central Oromia, Ethiopia. BMC Microbiol. 17(1):141.

Aygun, O. and Pehlivanlar, S. (2006): Listeria spp. In the raw milk and dairy products in Antakya, Turkey. Food Control. 17(8): 676679.

Baek, S.Y.; Lim, S.Y.; Lee, D.H.; Min, K.H. and Kim, C.M. (2000): Incidence and characterization of Listeria monocytogenes from domestic and imported foods in Korea. J Food Prot, 63(2): 186-189.
Baker, D.R.; Moxley, R.A.; Steele, M.B.; LeJeune, J.T.; Christopher-Hennings, J.; Chen, D.G.; Hardwidge, P.R. and Francis, D.H. (2007): Differences in virulence among Escherichia coli O157:H7 Strains isolated from human during disease outbreaks and from healthy cattle. Applied and environmental microbiology, 73(22): 7338-7346.

Bemrah, N.; Sanaa, M.; Cassin, M.H.; Griffiths, M.W. and Cerf, O. (1998): Quantitative risk assessment of human listeriosis from consumption of soft cheese made from raw milk. Preventive Veterinary Medicine, 37(14): 129-145.

Beneduce, L.; Spano, G. and Massa, S. (2003): Escherichia coli O157:H7 general characteristics, isolation and identification techniques. Annals Microbiol, 53 (4): 511527.

Boerlin, P.; Boerlin-Petzold, F. and Jemmi, T. (2002): Use of listeriolysin $\mathrm{O}$ and internalin $A$ in a seroepidemiological study of listeriosis in Swiss dairy cows. J. Clin. Microbiol. 41(3): 1055-1061.

Broseta, S.; Diot, M.A.; Bastian, S.; Riviere, J. and Cerf, O. (2003): Estimation of low bacterial concentration: Listeria monocytogenes in raw milk. Int. J. Food Microbiol., 80(1):115.

CFSPH (Center for Food Security and Public Health) (2009): Enterohemorrhagic Escherichia coli Infections. Institute for International Cooperation in Anima Biology. Iowa State, University-College of Veterinary Medicine. www.cfsph.iastate.edu/IICAB. C2009. Accessed on $14^{\text {th }}$ October 2015.

Coia, J.E.; Joghnston, J.; Steers, N.J.; Hanson, M.F.; Duffy, G.; Garvey, P.; Wasteson, Y.; Mc-Dowell, D. and Cola, J. (2001): A survey of the prevalence of Escherichia coli O157 in raw meat, raw cow's milk and raw milk cheeses in South-east Scotland. Int. J. Food Microbial., 66(1-2), 63-69.

De Boor, E. and Heuvelink, A.E. (2000): Methods for detection and isolation of Shiga toxin producing E.coli. J. Appl. Microbial, 88(S1): 133S-143S.

De Oliveira, L.P.; Silva, V.C. and Cirqueira, M.G. (2011): Study of Staphylococcus aureus in raw and pasteurized milk consumed in the Reconcavo area of the State of Bahia, Brazil. J. of Food Processing and Technology, 2(6): 128.

Dontorou, C.; Papadopoulou, C.; Filioussis, G.; Economou, V.; Apostolou, I.; Zakkas, G.; Salamoura, A.; Kansouzidou, A. and Levidiotou, S. (2003): Isolation of Escherichia coli O157: $H 7$ from foods in Greece. International Journal of Food Microbiology, 82(3): 273-279. 
EFSA (European Food Safety Authority) (2010): The community summary report on trends and sources of zoonoses, zoonotic agents and food borne outbreaks in the European Union in 2008. EFSA, 8(1): 1496.

Egyptian Standards (2005): Milk and Dairy Products, Egyptian organization for standardization and quality control, Directive No. 154-1, Arab Republic of Egypt, 2005.

Ekici, K.; Bozkurt, H. and Isleyici, O. (2004): Isolation of some pathogens from raw milk of different milch animals. Pakistan J. Nutrition, 3(3): 161-162.

El-Gedawy, A.A.; Abd-El ghafar, A.E.; Rasheed, N.; Mohammed, R.I.; Shukry, E. and ElKhawaga, E. (2016): Some studies on rabbit experimentally infected by E.coli O157:H7 isolated from raw milk. Assiut vet. Med. J, 62(148): 69-76.

El-Jakee, J.; Marouf, S.A.; Ata, N.S.; AbdelRahman, E.H.; El-Moez, S.I.A.; Samy, A.A. and El-Sayed, W.E. (2013): Rapid method for detection of Staphylococcus aureus enterotoxins in food. Global Veterinaria, 11(3): 335-341.

EL-Malt, L.M. and Abdel-Hameed, K.G. (2009): Occurrence of listeria species in raw cow's milk \& ice cream sold in Qena city. Assiut Vet. Med. J. 55 (121): 180-191.

El Marnissi, B.; Bennani, L.; Cohen, N.; Lalami, A.E.O. and Belkhou, R. (2013): Presence of Listeria monocytogenes in raw milk and traditional dairy products marketed in the north-central region of Morocco. African Journal of Food Science, 7(5): 87-91.

FDA (Food and Drug Adminstration) (1998): Bacteriological Analytical Manual, $8^{\text {th }}$ Edition, AOAC International, Gaithersburg, USA.

Gillespie, I.A.; Adak, G.K.; O'brien, S.J. and Bolton, F.J. (2003): Milkborne general outbreaks of infectious intestinal disease, England and Wales, 1992-2000. Epidemiol. Infect, 130(3): 461-468.

Grant, M.A.; Hedberg, C.; Johnson, R.; Harris, J.; Logue, C.M.; Meng, J.; Sofos, J. and Dickson, J. (2011): The Significance of Non-O157 Shiga Toxin-producing Escherichia coli in Food Public Health Agency of Canada. Food Prot. Tren., 31(1): $33-45$.

Griffiths, M.W. (1989): Listeria monocytogenes: Its importance in dairy industry. Journal of the Science of Food and Agriculture, 47:133158.

Gündog`an, N.; Citak, S. and Turan, E. (2006): Slime production, DNase activity and antibiotic resistance of Staphylococcus aureus isolated from raw milk, pasteurised milkand ice cream samples. Food Control,
17: 389-392.

Harvey, J. and Gilmour, A. (1996): Isolation and identification of staphylococci from milk powders produced in Northen, Ireland. J. Appl. Bacteriol, 68: 433-438.

Heuvelink, A.E.; Van Den Biggelarr, F.L.A.M.; Zwartkruis-Nahuis, J.T.M.; Herbes, R.G.; Huyben, R.; Nagelkerke, N.; Melchers, W. J.G.; Monnes, L.A.H. and De Boer, E. (1998): Occurrence of verocytotoxinproducing Escherichia coli O157 on Dutch dairy farms. Journal of Clinical Microbiology, 36 (12): 3480-3487.

Hitchins, A.D. (2001): Transforming contamination prevalence data into concentrations of foodborne microbial risk assessments: $L$. monocytogenes, CFSAN, FDA, Washington D.C. identification techniques. Annals Microbiol., 53 (4): 511-527.

Issa, G.; Khraman, T. and Kahraman, B. (2010): Prevalence of Listeria monocytogenes, salmonella spp. and Escherichia coli $O$ 157:H7 in raw milk. J. Fac. Vet. Med. Istanbul Univ., 36(1), 57-63.

Jahan, M.; Rahman, M.; Parvej, M.S.; Chowdhury, S.M.Z.H.; Haque, M.E.; Talukder, M.A.K. and Ahmed, S. (2015): Isolation and characterization of Staphylococcus aureus from raw cow milk in Bangladesh. J. Adv. Vet. Anim. Res., 2(1): 49-55.

Jay, M.J.; Loessner, J.M. and Golden, A.D. (2005): Staphylococcal gastroenteritis. In: Modern Food Microbiology. $7^{\text {th }}$ edition, Springer: 545-566.

Kadariya, J.; Smith, T.C. and Thapaliya, D. (2014): Staphylococcus aureus and staphylococcal food-borne disease: an ongoing challenge in public health. BioMed research international, Volume 2014:1-9.

Kamat, M.Y.; Sulebele, G. and Nirupama, S. (1991): A comparative evaluation of media for enumeration of enterotoxigenic staphylococci by selective enrichment technique. J. Food Sci. Technol. India, 28(6): 381-383.

Kevenk, T.O. and Gulel, G.T. (2016): Prevalence, antimicrobial resistance and serotype distribution of Listeria monocytogenes isolated from raw milk and dairy products. Journal of Food Safety, 36: 11-18

Kok, T.; Worswich, D. and Gowans, E. (1996): Some serological techniques for microbial and viral infections. In Practical Medical Microbiology (Collee, J.; Fraser, A.; Marmion, B. and Simmons, A., eds.), $14^{\text {th }}$ ed., Edinburgh, Churchill Livingstone, U.K.

Kumar, A.; Grover, S. and Batish, V.K. (2015): Exploring specific primers targeted against different genes for a multiplex PCR for detection of Listeria monocytogenes. 3 Biotech, 5(3): 261-269. 
Leite, C.C.; Guimarães, A.G.; Assis, P.N.; Silva, M.D. and Andrade, C.S. (2002): Qualidadebacteriológica doleite integral (tipo C) comercializado em Salvador-Bahia. Rev. Bras. Saúde Prod. Anim., 3: 21-25.

Mason, W.J.; Blevins, J.S.; Beenken, K.; Wibowo, N.; Ojha, N. and Smeltzer, M.S. (2001): Multiplex PCR Protocol for the Diagnosis of Staphylococcal Infection. Journal of clinical microbiology, 39(9): 3332-3338.

Mauro, S.A. and Koudelka, G.B. (2011): Shiga Toxin: Expression, Distribution, and Its Role in the Environment. Toxins, 3(6): 608-625.

Meshref, A.M.S. (2007): Prevalence of salmonella and Ecoli $O 157$ in some foods. Beni-Suef Vet. Med. J. $5^{\text {th }}$ Scientific conference, 73-78.

MPI NZ (Ministry for Primary Industries, New Zealand) (2013): An Assessment of the Effects of Pasteurisation on Claimed Nutrition and Health Benefits of Raw Milk MPI Technical Paper No: 2014/13 ISBN No: 978-0-478-43209-1. ISSN New Zealand Government No: 2253-3923, October.

Naylor, S.W.; Low, J.C.; Besser, T.E.; Mahajan, A.; Gunn, G.J.; Pearce, M.C.; McKendrick, I.J.; Smith, D.G. and Gally, D.L. (2003): Lymphoid follicle-dense mucosa at the terminal rectum is the principal site of colonization of enterohemorrhagic Escherichia coli O157: $H 7$ in the bovine host. Infection and immunity, 71(3): 15051512.

Nermano, T.G.; La Salandra, G.; Dambrosia, A.; Quaglia, N.C.; Corrent, M.; Paris, A.; Santagada, G.; Firina, A.; Crisitte, E. and Celano, G.V. (2007): Occurance, characterization and antimicrobial resistance of enterotoxigenic staphylococcus aureus strains isolated from meat and dairy products. Int. J. Food. Microbial, 115(3): 290-296.

Padilha, M.R.; Fernandes, Z. F.; Leal, T.A.; Leal, N.C. and Almeida, A.M. (2001): Isolation of pathogenic bacteria in pasteurized type $\mathrm{C}$ milk sold in Recife City, Pernambuco, Brazil. Rev Soc Bras Med Trop, 34(2): 167171.

Pal, M. (2014): Spoilage of dairy products due to fungi. Beverage and Food World ,41.

Pourhassan, M. and Taravat, N. (2011): The Spatial Distribution of bacteria pathog ens in raw milk consumption on Malayer City, Iran. Shiraz E. Medical J., 12(1): 1-9.

Rahimi, E.; Momtaz, H.; Sharifzadeh, A.; Behzadina, A.; Ashtari, M.S.; Esfahani, S.Z.; Riahi, M. and Momeni, M. (2012): Prevalence and antimicrobial resistance of Listeria species isolated from traditional dairy products in Chahar Mahal and Bakhtiyari, Iran. Bulgarian Journal of Veterinary Medicine, 15(2): 115-122.
Rall, V.L.M.; Vieira, F.P.; Rall, R.; Vieitis, R.L.; Fernandes, Jr. A.; Candeias, J.M.G.; Cardos, K.F. and Arau'jo, Jr.J.P. (2008): PCR detection of staphylococcal enterotoxin genes in Staphylococcus aureus strains isolated from raw and pasteurized milk. Veterinary Microbiology, 132 (10): 408-413

Rey, J.; Blanco, J.E.; Blanco, M.; Mora, A.; Dahbi, G.; Alonso, J.M.; Hermoso, M.; Hermoso, J.; Alonso, M.P.; Usera, M.A. and González, E.A. (2003): Serotypes, phage types and virulence genes of Shiga-producing Escherichia coli isolated from sheep in Spain. Veterinary microbiology, 94(1): 4756.

Sammarco, M.L.; Ripabelli, G.; Fanelli, I. and Grasso, G.M. (2005): Prevalence of Listeria spp. in dairy farm and evaluation of antibiotic-resistance of isolates, J. Ann Ig. 17(3): 175-183.

Seyoum, E.T.; Woldetsadik, D.A.; Mekonen, T.K.; Gezahegn, H.A. and Gebreyes, W.A. (2015): Prevalence of Listeria monocytogenes in raw bovine milk and milk products from central highlands of Ethiopia. J Infect Dev Ctries, 9(11): 1204-1209.

Shamloo, E.; Jalali, M.; Mirlohi, M.; Madani, G.; Metcalf, D. and Merasi, M.R. (2015): Prevalence of Listeria species in raw milk and traditional dairy products in Isfahan, Iran. International Journal of Environmental Health Engineering, 4(1):1.

Siriken, B.; Pamuk, S.; Ozakin, C.; Gedikoglu, S. and Eyigor, M. (2006): A note on the incidence of Salmonella spp., Listeria spp and Escherichia coli O157:H7 serotypes in Turkish sausage (Soudjouck). Meat Science, 72(1): 177-181.

Upton, P. and Coia, J.E. (1994): Outbreak of Escherichia Coli 0157 Infection associated with Pasteurized milk supply. The Lancet 344(8928): 1015.

Vahedi, M.; Nasrolahei, M.; Sharif, M. and Mirabi, A.M. (2013): Bacteriological study of raw and unexpired pasteurized cow's milk collected at the dairy farms and super markets in Sari city in 2011. J. Prev. Med. Hyg, 54(2): 120-123.

Wang, G. and Doyle, M.P. (1998): Survival of enterohemorrhagic Escherichia coli O157:H7 in water. Journal of Food Protection, 61(6): 662-667.

Wang, G.; Zhao, T. and Doyle, M.P. (1997): Survival and growth of Escherichia coli O157:H7 in unpasteurized and pasteurized milk. Journal of Food Protection, 60 (6): 610-613.

Wijendra, W.A.S.; Kulathunga, K.K.C. and Ramesh, $R$. (2014): First of Listeria monocytogenes serotypes detected from milk and milk products in Sri Lanka. Adv. Anim. Vet. Sci. 
2(55): 11-16.

Zeinhom, M.M.A. (2011): Monitoring of enteric pathogens in milk and some dairy products with special reference for Enterobacter sakazakii and E.coli O157:H7. ph.D. Thesis, Fac. Vet. Med., Beni-Seuf University.
Zhao, T.; Doyle, M.P.; Shere, J. and Garber, L. (1995): Prevalence of enterohemorrhagic Escherichia coli O157:H7 in a survey of dairy herds. Applied and Environmental Microbiology, 61 (4), 1290-1293.

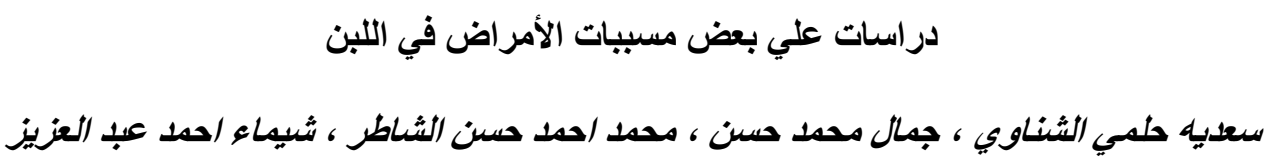

E-mail: shimaa_ahmed1415@yahoo.com Assiut University web-site: www.aun.edu.eg

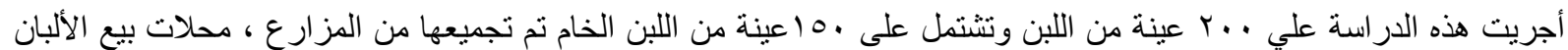

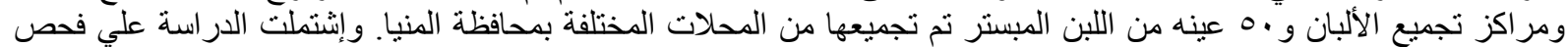

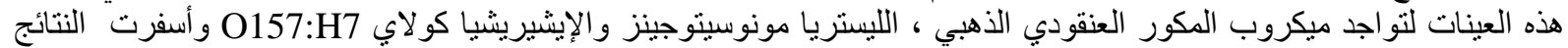

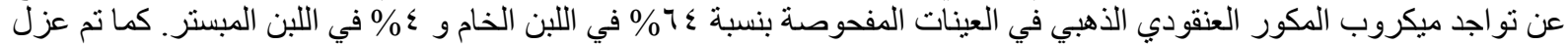

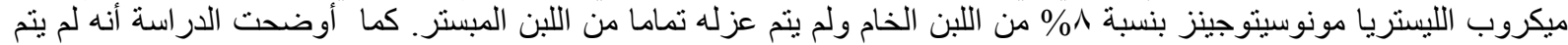

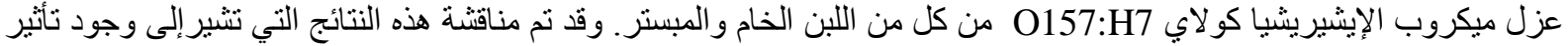

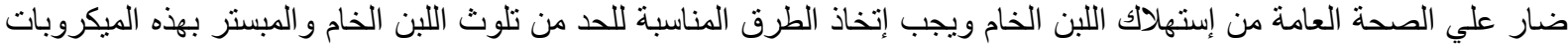

